\title{
Fluoride in Groundwater and its Implications in West Gonja District of Ghana*
}

\author{
E. Arhin and M. Affam
}

Arhin, E. and Affam, M., (2009). "Fluoride in Groundwater And its Implications in West Gonja District of Ghana”, Ghana Mining Journal, Vol. 11, pp. 47 - 52.

\begin{abstract}
Fluoride levels in groundwater may cause either enamel fluorosis or dental caries depending on their concentrations when consumed. Research has shown that an estimated $60 \%$ of the total intake of fluoride is through drinking water (Selwitz et $a l$, 2007). Boreholes sunk in the West Gonja district had their groundwater analyzed for fluoride. Using World Health Organisation (WHO) standard of $(0.5-1.5 \mathrm{mg} / \mathrm{l})$ as basis, result revealed that concentration deviates from standard set by WHO. Test boreholes drilled in the communities showed three broad categorisations of fluoride levels in the groundwater as; $<0.5 \mathrm{mg} / \mathrm{l}$ (inadequate), $0.5-1.5 \mathrm{mg} / \mathrm{l}$ (adequate) and $1.5-4.8 \mathrm{mg} / \mathrm{l}$ (excessive). Generally, the distribution in the district varied between 0.1 to $4.8 \mathrm{mg} / \mathrm{l}$

The concentration of fluoride was again spatially analysed to predict areas prone to fluorosis and dental caries diseases. The findings showed that most communities in the district within the western portion had generally low concentrations while those towards the east had elevated levels. The reappraisal of fluoride concentrations in groundwater resulted in the creation of geochemical atlas map of West Gonja District that showed the excessive, adequate and deficient concentrations of fluoride and potential fluorosis or dental caries localities based on the permissible levels.
\end{abstract}

\section{Introduction}

The degree of rock weathering in humid tropical region appears to be faster compared to the other climatic areas, probably due to high temperature and rainfall patterns. The phenomenon of rock weathering results in continuous landscape variations, enhancing rapid landform modifications (Anand and Broekert, 2005). Many health-related problems are known to be associated with geological materials that the groundwater flows through. For instance, excess and deficient amount of fluoride in drinking water has been reported to be associated with endemic dental caries and skeletal fluorosis in several geographical areas across the world. The World Health Organisation (WHO) therefore provides standard of concentration of fluoride in drinking water as $(0.5$ to $1.5 \mathrm{mg} / \mathrm{l})$ for parts of the world (Anon, 2006a), while United State Public Health Service (USPHS) puts their limit between (0.7 - 1.2) ppm (Mary and Gavin, 2008).

There is some concern about cumulative effect of consuming fluoride in drinking water. Researchers have discovered that moderate amount of fluoridation prevents tooth decay, however it deficiency or excessiveness can pose serious health problems especially during early childhood stages (Hill and Petrucci, 1999). Fluorine $(F)$ is a naturally occurring chemical element from which Fluoride $(F)$ is obtained. $F$ is useful to animals, plants and human health in small quantities at parts per million or parts per billion (ppm /ppb) levels. Naturally, this element is introduced into ground water source primarily through weathering of rocks and also through dissolution of naturally occurring minerals and ores. However, just about 50 million people worldwide receive fluoride naturally at recommended levels (Anon, 2004), the rest have it either deficient or excess. Hence, over 400 million people across the world use fluoridated water to some extent. The natural process is such that underlying rocks of the formation do weather and may release both deficient and excessive amounts of fluoride into the ground water.

In parts of Northern and Upper East regions of Ghana, concentration of fluoride in groundwater has been reported to range from 0.11 to $4.5 \mathrm{mg} / \mathrm{l}$ (Apambirie et al, 1990), thus, posing serious health challenge. Against this background, it is proper from the current disposition to analysis the groundwater within the formation in order to assess the health risks posed by some metals and trace elements in the groundwater. Geological formation of the West Gonja district was therefore test-drilled for groundwater.

Subsequently, the water was analysed for fluoride and other elemental concentrations. A geochemical atlas map of fluoride concentration using the hydro -geochemical data of the boreholes water samples

* Manuscript received September 11, 2009

Revised version accepted December 2, 2009 


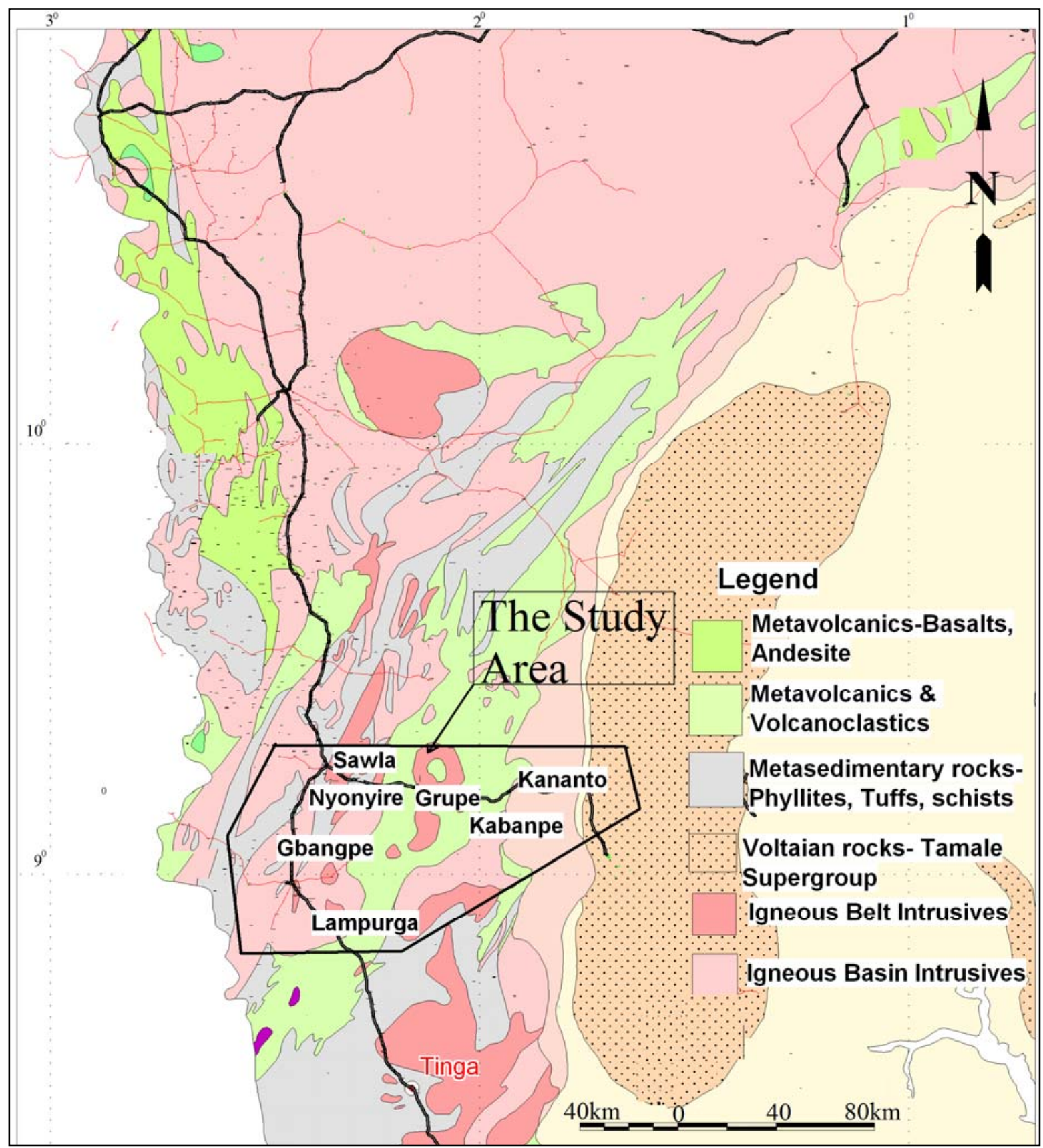

Fig. 1 Geological Map of Northwest Ghana showing the Study Area (Modified after Anon, 2006b)

was created with the aid of geographic information systems (GIS). Areas considered deficient and abnormal high, having potential primary health problems such as enamel fluorosis and dental caries were defined.

\section{Geological Setting and Mineralisa- tion}

The West Gonja District area lies within Birimian and partly in the Voltaian basin. The beds consist generally of varieties of arenaceous and argillaceous sediments such as sandstones and shales (Fig.1). Some conglomerate interbeddings, few carbonate sequences and clastic units do exist. The area is relatively flat lying, characterised by gentle dipping beds striking north-easterly (Kesse, 1985).

The Voltaian is reported to be underlain by the Birimian Precambrian rocks and occasionally intruded by both belt and basin granitoids (Hirdes and Davis, 1993 and Griffis et al, 2002). The Birimian beds are older, generally steeply dipping with dip amount of between $55^{\circ}$ to $65^{\circ} \mathrm{SE}$. The granitoids are foliated consisting of hornblende and biotite-rich minerals. Diorites and: granodiorites bearing intrusives with quartz associated are common. Doleritic dykes seldomly occur within the formation. 


\section{Occurrence of Fluoride}

Fluoride exists naturally in water and it is derived from fluorine, a toxic pale yellow gaseous element of the halogen group. It is among the most known reactive and oxidizing agents. Fluoride is the anion $(F)$, a reduced form of fluorine $(F)$. Ironically, in most groundwater about $95 \%$ of total fluoride is made up of $F$ ion with minor percentage of magnesium fluoride complex $\left(\mathrm{MgF}^{+}\right)$and other trace compounds forming 5\% (Selwitz, et al, 2007). Normally, organic and inorganic compounds containing the element are often called fluoride.

It has been proven that fluoride is an essential nutrient and helps prevent and even reverse the early stages of tooth decay caused by bacteria called streptococcus mutans and lactobacillus when appropriate quantities are used (Olivares and Uauy, 2005). Fluoride exerts it effect by interfering with demineralising mechanism of tooth decay. Tooth enamel is a complex calcium phosphate called hydroxyapatite (Hill and Petrucci, 1999). Fluoride ion replaces some of the hydroxide ions forming harder mineral hydroxyapatite.

$\mathrm{Ca}_{5}\left(\mathrm{PO}_{4}\right)_{3} \mathrm{OH}+\mathrm{F}^{-} \rightarrow \mathrm{Ca}_{5}(\mathrm{PO})_{3} \mathrm{~F}+\mathrm{OH}$

Hydroxyapatite + fluoride $\rightarrow$ Mineral hydroxyapatite + hydroxyl

Therefore, scientific evidence continues to support fluoride use, when consumed within recommended levels of between $0.5-1.5 \mathrm{mg} / \mathrm{l}$ set by WHO or between (0.7 - to 1.2) ppm by mass recommended by United State Public Health Service (USPHS) and American Dental Association (ADA) (Mary and Gavin, 2008).

Fluoride occurs in sedimentary rocks like limestone and sandstones that are commonly found in the West Gonja District. Igneous rocks like granites and those intruding the Birimian volcanic belt in parts of Northern and Upper East regions also contain appreciable quantities of fluoride. It has been observed usually that the surface water does not contain high fluoride but the groundwater may contain some excess concentration if the underlying rocks are associated with fluoride rich rocks (Sahelian, 2007). When water percolates through fluoride-rich rock, it leaches out the fluoride from the rocks after which the solution drains into the stream and the groundwater system. The residues remain in the regolith for a long time creating deformation problems.

\subsection{Under and Over Exposure to Flouride}

Opponents of water fluoridation often questions fluoride intake on the grounds of its safety and efficacy. Just like most medications, in-take of large quantities of fluoride has been proven to be quite harmful with observable symptoms. Fluoride toxicity therefore occurs when amount in excess of the stipulated level set by WHO is consumed. It causes teeth discoloration or molting of the permanent teeth referred to as fluorosis (Mary and Gavin, 2008). This disease according to experts is rather critical for children in their teeth development stage of below eight years old. The teeth discoloration or change is quite a slow process, usually subtle, but the eventual colour change becomes glaring after sometime. It is rather difficult to remedy the situation once it initiates. Over exposure to fluoride therefore put consumers especially kids at risk of severe enamel fluorosis. High natural fluoride levels are also associated with calcium-deficiency, alkaline and soft water (Zsvath, 2009).

On the other hand if fluoride is under consumed, or taken in less quantity than required, tooth decay initiates, resulting in dental caries (Gavin, 2008). With deficient fluoride levels, bacteria are able to penetrate the enamel and demineralise the teeth. Either fluoridation or defluorodation may be required to combat effect of naturally low or high fluoride content in groundwater.

\section{Data Acquisition and Analysis}

The hydro-geochemical data was collected from boreholes sunk for groundwater in West Gonja District of northern Ghana. Large and small communities where the groundwater was sampled include Damange, Sawla, Diaboya, Grupe, Kalblippe, Larabanga, Kablima Kananto and Tachari. This paper however reports on four critical elements found in the groundwater. The borehole water samples were analysed at a commercial laboratory for fluoride $\left(\mathrm{F}^{-}\right)$, lead $(\mathrm{Pb})$, manganese $(\mathrm{Mn})$ and total iron (Fe), which are observed to impact on human health. The results from the anal-

ysis of the groundwater samples in the district are presented as per the sample location (Table 1). The WHO standards for the elemental magnitudes permissible are: $F=1.5 \mathrm{mg} / \mathrm{l}$, total $F e=0.3 \mathrm{mg} / \mathrm{l}, \mathrm{Mn}$ $=0.1 \mathrm{mg} / \mathrm{l}$ and $\mathrm{Pb}=0.05 \mathrm{mg} / \mathrm{l}$. As observed from the Table 1, abnormality observed regarding fluoride concentration was much higher than the other elements.

The abnormalities could pose a health threat to the consuming public. Medical implications suggest that the excessive fluoride contents in the groundwater could likely lead to dental health problems such as dental caries, skeletal and dental fluorosis in the district. The result of the concentration of fluoride obtained from the borehole water was therefore developed into a geochemical atlas to show potential areas in the district to be affected 
Table 1 Hydro-geochemical Data from Groundwater Analysis in West Gonja

\begin{tabular}{|c|c|c|c|c|c|}
\hline Latitude & Longitude & $\begin{array}{l}\mathrm{F}^{-} \\
(\mathrm{mg} / \mathrm{l})\end{array}$ & $\begin{array}{l}\text { Total } \\
\text { Fe } \\
(\mathrm{mg} / \mathrm{l})\end{array}$ & $\begin{array}{l}\mathrm{Mn} \\
(\mathrm{mg} / \mathrm{l})\end{array}$ & $\begin{array}{l}\mathrm{Pb} \\
(\mathrm{mg} / \mathrm{l})\end{array}$ \\
\hline $9^{\circ} 09.339$ & $1^{\circ} 51 . .138$ & 0.3 & 0.25 & 0.100 & 0.005 \\
\hline $9^{\circ} 12.896$ & $2^{\circ} 01.814$ & 0.4 & 0.09 & 0.050 & $<0.005$ \\
\hline $9^{\circ} 09.201$ & $1^{\circ} 51.217$ & 0.4 & 0.46 & 0.070 & $<0.005$ \\
\hline $9^{\circ} 14.205$ & $1^{\circ} 00.258$ & 0.5 & 0.50 & 0.050 & $<0.006$ \\
\hline $9^{\circ} 09.305$ & $1^{\circ} 15.056$ & 0.3 & 0.10 & 0.050 & $<0.007$ \\
\hline $9^{\circ} 14.180$ & $1^{\circ} 00.257$ & 3.6 & 0.06 & 0.070 & $<0.008$ \\
\hline $9^{\circ} 02.482$ & $1^{\circ} 48.090$ & 2.5 & 0.21 & 0.060 & $<0.009$ \\
\hline $9^{\circ} 07.215$ & $1^{0} 53.568$ & 0.4 & 0.11 & 0.400 & 0.026 \\
\hline $9^{\circ} 01.966$ & $1^{\circ} 48.167$ & 0.9 & 0.21 & 0.200 & 0.310 \\
\hline $9^{\circ} 06.899$ & $1^{0} 53.572$ & 0.3 & 0.24 & 0.180 & $<0.005$ \\
\hline $9^{\circ} 09.787$ & $1^{0} 27.731$ & 0.9 & 0.14 & 0.020 & $<0.005$ \\
\hline $9^{0} 32.588$ & $1^{0} 26.198$ & 0.4 & 0.42 & 0.340 & $<0.005$ \\
\hline $9^{\circ} 10.140$ & $1^{0} 30.418$ & 0.2 & 0.13 & 0.080 & $<0.005$ \\
\hline $8^{0} 50.374$ & $1^{0} 25.821$ & 0.3 & 0.12 & 0.090 & $<0.005$ \\
\hline $9^{\circ} 09.923$ & $1^{0} 30.628$ & 0.2 & 1.19 & 0.030 & $<0.005$ \\
\hline $8^{0} 50.388$ & $1^{0} 26.002$ & 0.5 & 1.31 & 0.050 & $<0.005$ \\
\hline $8^{0} 57.112$ & $1^{0} 13.381$ & 0.1 & 3.12 & 0.050 & $<0.005$ \\
\hline $9^{\circ} 19.073$ & $0^{\circ} 59.273$ & 0.8 & 0.21 & 0.040 & $<0.005$ \\
\hline $8^{0} 56.725$ & $1^{0} 13.449$ & 0.8 & 0.45 & 0.080 & 0.010 \\
\hline $8^{\circ} 42.839$ & $1^{\circ} 08.703$ & 1.6 & 0.16 & 1.100 & $<0.005$ \\
\hline $8^{\circ} 44.602$ & $1^{\circ} 11.977$ & 4.8 & 0.51 & 0.040 & 0.010 \\
\hline $8^{\circ} 42.857$ & $1^{\circ} 08.703$ & 2.4 & 0.37 & 0.030 & 0.010 \\
\hline $8^{\circ} 43.907$ & $1^{\circ} 02.078$ & 0.4 & 0.43 & 0.050 & $<0.005$ \\
\hline $9^{\circ} 07.622$ & $1^{0} 11.498$ & 1.3 & 0.45 & 0.070 & 0.001 \\
\hline $8^{\circ} 43.960$ & $1^{\circ} 02.002$ & 0.6 & 0.08 & 0.020 & $<0.005$ \\
\hline $8^{\circ} 44.368$ & $1^{\circ} 09.793$ & 0.8 & 0.06 & 0.090 & $<0.005$ \\
\hline $8^{\circ} 44.683$ & $1^{\circ} 04.988$ & 0.7 & 0.45 & 0.080 & $<0.005$ \\
\hline $9^{\circ} 07.617$ & $1^{\circ} 11.478$ & 4.1 & 0.13 & 0.004 & $<0.005$ \\
\hline $8^{\circ} 44.752$ & $1^{\circ} 04.983$ & 0.6 & 0.10 & $<0.005$ & $<0.005$ \\
\hline $8^{0} 50.347$ & $1^{0} 25.785$ & 0.4 & 0.58 & 0.800 & 0.020 \\
\hline $8^{\circ} 44.707$ & $1^{\circ} 04.927$ & 0.6 & 0.14 & 0.040 & $<0.005$ \\
\hline $8^{0} 59.103$ & $0^{\circ} 58.905$ & 0.2 & 0.31 & 0.070 & 0.010 \\
\hline
\end{tabular}

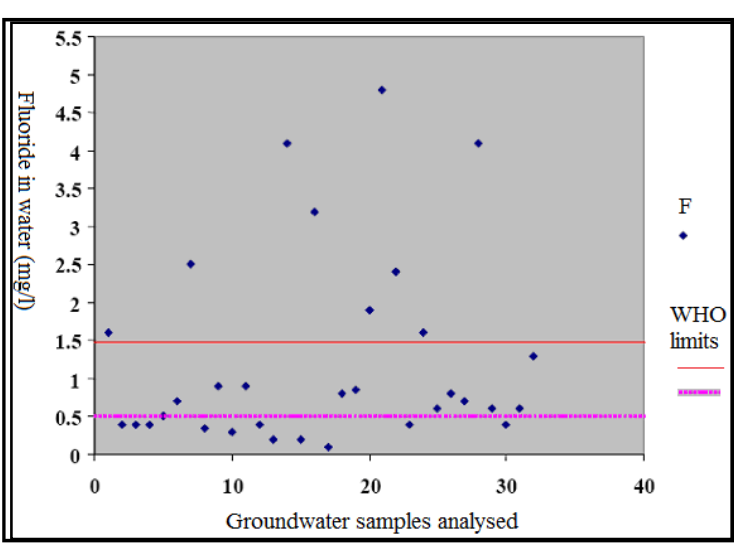

Fig. 2 Scatter Plot of Fluoride Concentrations in Groundwater showing Levels above and below WHO's Permissible Limits

by the associated dental health problem. This was done by creating a scatter plot to show the distribution of the fluoride concentrations (Fig.2). The permissible concentrations of fluoride against the WHO's tolerance limits for human consumption in drinking water were observed from the scatter plot using non-spatial analysis. The geochemical map showing spatial distribution of fluoride concentra- tions in groundwater using geographical information system was created to enhance appreciation of the menace (Fig. 3).

Although some sporadic anomalous values can be observed within the heavy metal concentration in the ground water, especially $\mathrm{Fe}$ and $\mathrm{Pb}$ and considered equally undesirable, no major health problem associated with these elements has been reported. Except one high sample value (considered to be an outlier), the $M n$ level is generally good as it falls far below WHO limit.

Boreholes that recorded fluoride concentrations $>1.5 \mathrm{mg} / \mathrm{l}$ were grouped and were classified as dental and skeletal fluorosis zone, whereas boreholes with concentration $<0.5 \mathrm{mg} / \mathrm{l}$ fluoride areas were also identified as dental caries zone. It must be noted that to acquire the fluorosis disease also depends on other factors such as age, quantity of water consumed and length of in-take of the fluoridated water

\section{Discussions}

Variable concentrations of fluoride in the groundwater, which is the main source of drinking water in the West Gonja District deviates considerably from the permissible levels of 0.5 to $1.5 \mathrm{mg} / \mathrm{l} \mathrm{ac-}$ cording to the World Health Organisation (WHO) threshold (Anon, 2006a). The implications are that dental caries as well as skeletal flourosis may be a possible health problem within the communities. Already, evidence of fluorosis case is reported in sections of the district, but their linkages with the underlying rocks are yet to be proven. In other parts of the world which have the prevalence of this disease, observation indicates the formation is underlain by sandstone and granitic rocks (Mukhopadhyay et al, 2004).

Critical ground investigation of the West Gonja District show that groundwater is the most dominant source of drinking water housed dominantly in the sandstones. Test boreholes drilled in the communities showed three broad categorisation of fluoride concentrations in the groundwater as; $<0.5$ mg/l (inadequate), 0.6-1.6 mg/l (adequate) and 1.5 - 4.8mg/l (excessive). Generally, the fluoride concentrations ranged between 0.1 to $4.8 \mathrm{mg} / \mathrm{l}$. If the low and elevated levels of fluoride in the groundwater are to be strictly followed as shown in Fig. 1 , then, on the basis of the dental disease, eleven communities may suffer from dental caries in low concentration areas whereas perhaps nine communities may suffer from dental and skeletal fluorosis. Despite this associated medical threats with the groundwater, its disuse is difficult to encourage now since other options are non existent.

Using World Health Organization (WHO) standard of $0.5-1.5 \mathrm{mg} / \mathrm{l}$ as a basis, results revealed con- 


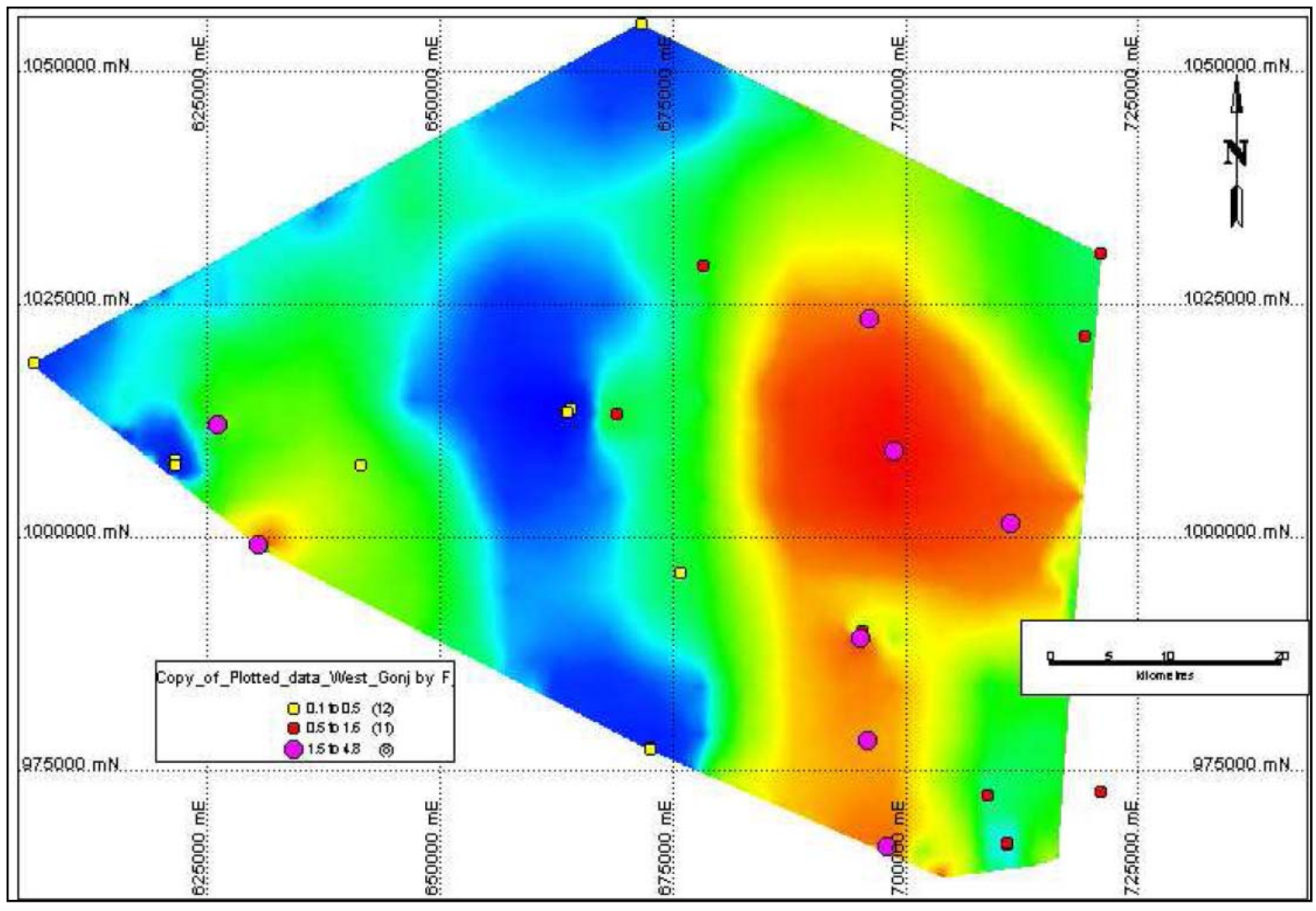

Fig. 3 Spatial Distribution of Fluoride Concentrations in Groundwater in West Gonja District

centration of fluoride ranging from inadequate to excess amount. This condition underscores the need to re-evaluate the groundwater condition and to find possible solutions. The area is observed to be underlain predominantly by sandstones seated on rocks of Birimian origin. Sporadic granitic intrusion is not uncommon. Though the origin of fluoride in these areas has not been studied thoroughly, it appears to have a linkage with the geological formation. Low and high concentration of fluoride tends to follow the stratigraphy of the underlying rocks. As shown in Fig. 3, the eastern block of the district appears to have high fluoride concentration. However, this pattern is not continuous, the signatures rather appear as discrete patches sandwiched by low concentrations. The western margin and the middle portion however house more low fluoride concentrations than the east.

Considering the spatial patterns depicted by fluoride, geological assessment suggests that the areas endemically fluorosis is underlain by variable sedimentary materials (i.e., sandstones, shale, etc). Since the prevalence of these dental health problems in the area is cannot be attributed to poor dental hygiene due to the large number of people involved and the unique geographical location, it is therefore not out of place to suggest probable genetic link between the rock types which house the groundwater and the disease. This observation may however need further detailed geological investigation and perhaps some medical assessment, to establish the genetic linkages of flourosis and dental caries disease to the type of litholgical units causing the menace.

In general, distribution of fluoride in groundwater is not uniform, it appears sporadic, stretching out intermittently towards northern part of the district. The eastern block of the district has high concentration, which may be characterised by dental and skeletal fluorosis. This area then grades into dental caries zone based on the low concentrations of fluoride in the environment.

\section{Conclusion}

Based on the spatial distribution and concentrations of fluoride in West Gonja District of northern Ghana, the study concludes that:

- fluoride concentrations in the groundwater range from; <0.6mg/l (inadequate), 0.6-1.6 $\mathrm{mg} / \mathrm{l}$ (adequate) to 1.6 - $4.8 \mathrm{mg} / \mathrm{l}$ (excessive). Generally, the distribution lies within the limit of $0.1 \mathrm{mg} / \mathrm{l}$ to $4.8 \mathrm{mg} / \mathrm{l}$ within the district. The patterns as observed may be linked to the variable rock units that underlie the district.

- extensive geochemical mapping that pre- 
dicts possible fluorosis or dental caries disease within the locality has been defined to aid remediation activities.

- the western margin and the middle portion however house more low fluoride concentrations in the groundwater while the east has elevated levels.

- whilst having varying concentrations probably based on geological materials, the study ascertains that, thorough investigation into the actual lithological units having anomalous low or high concentrations of fluoride causing the menace must be defined.

\section{Recommendation}

It is recommended that since the study covers relatively smaller geographical area, it would be prudent to generate extensive geochemical atlas map of naturally fluoridated and non fluoridated groundwater for the entire Northern and Upper East regions to sensitise the populace and assist in remediation process.

\section{Acknowledgment}

The authors are grateful to the Community, Water and Sanitation Agency of the Northern Region of Ghana for making the data available for analysis. We are also thankful to the anonymous reviewers for their support.

\section{References}

Anand, R. R. and de Broekert, P., (2005), Regolith Landscape Evolution across Australia: A Compilation of Regolith Landscape Case Studies with Regolith Landscape Evolution Models; Published by CRCLEME, Bentley, WA, 6102, $354 \mathrm{pp}$.

Anon., (2004), The extent of water fluoridation 'one in a million' the facts about water fluoridation. $2^{\text {nd }}$ ed., Manchester. British Fluoride Society, pp. 55-80.

Anon., (2006a), WHO Guidelines for DrinkingWater Quality, First Addendum to the Third edition, Volume 1, 576 pp.

Anon., (2006b), Mineral resource and ore reserve report. Newmont Ahafo mine, (unpublished) pp. 16-36.

Apambrie, W. R. and Boyle D. R., (1990), Genesis and Geochemistry of Fluorosis areas in Upper Regions of Ghana. Journal of Environmental Geochemistry and Health, Amsterdam, Amazon Press.

Griffis, J., Barning, K., Francis L., Agezo, F. L. and Akosa, F., (2002), Gold Deposits of Ghana. Report prepared on behalf of Ghana Mineral Commission, Accra, Ghana, 432 pp.

Kesse, G. O., (1985), Rock and Mineral Resource of Ghana. Balkema Publishing, Rotterdam, Netherlands, pp. 10-50.

Hill, J. W. and Petrucci, R. H., (1999), General chemistry: An integrated approach. $2^{\text {nd }}$ edition, Prentice Hall, New Jessey, 1072pp.

Hirdes, W. and Davis, D. W., (1993), Reassessment of Absolute and Relative Ages of Early Proterozoic Granitoids and some Super Crustal Rocks in Ghana on the Basis of U/Pb Zircon Monazite and Rutile Dating. Bundensanstalt for Geowissenschaften and Rohstoffe, Hanover, pp. 193-199.

Mary, L. and Gavin, M. D., (2008), Fluoride and water. http//www.kidshealth.org/fluoride.html, Jun.,2009.

Mukhopadhyay, D. K., Deb, S. K. and Hakravorty P.N.,(2004), Workshop on medical

geology, 2004 , IGCP, Proceedings, 3-4 February, 2004, Nagpur, India, Special Publication, Geological Survey of India, pp.454.

Oliveres, M. and Uauy, R., (2005), Essentials nutrients in drinking water. World Health Organisation, pp. 41-60.

Sahelian, M. D., (2007), Fluoride water information; http://www.raysahelian.com. $\mathrm{M} \mathrm{a} \mathrm{y} \mathrm{.,}$ 2009.

Selwitz, R. H., Ismail, A. L. and Pitts, N. B., (2007), Dental caries. Lancet, 369 (9555), pp. 9 -51 .

Zsvath, D. L., (2009), Fluoride and environmental health: a review. Rev. Environ. and Sci. Biotechnol 8 (1), pp. 59-79.

\section{Authors}

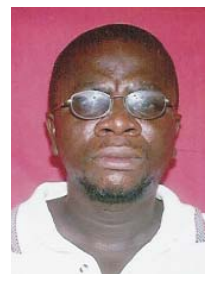

E. Arhin is currently a lecturer in Earth and Environmental Sciences Department, of University for Development Studies, Navrongo campus. He is a graduate from Kwame Nkrumah University of Science and Technology, Kumasi where he obtained his BSc in Geological Engineering. He holds MPhil degree in Geological Engineering from University of Mines and Technology, Tarkwa. He has since graduation worked for several mining companies in Ghana including Newmont Ghana projects in the north. He is a member of GhIG and has his specialization in geochemistry and regolith geology.

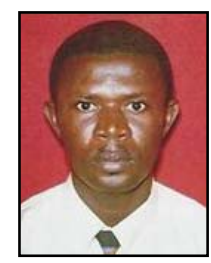

M. Affam is a lecturer in Geotechnical Engineering at University of Mines and Technology, Tarkwa, Ghana. He holds MSc degree in Mineral Exploration and BSc in Geological Engineering from Kwame Nkrumah University of Science and Technology, Kumasi. He is currently a $\mathrm{PhD}$ student researching actively in rockburst potential in Ashanti deep mine. He has since graduation worked for a number of mining and exploration companies in Ghana. He is a member of a team of experts that provide geotechnical consultancy services to mining and allied companies. He is a member of GhIE, GhIG and CIM/ICM. 